\title{
God and the God-Image: An Extended Reflection
}

\author{
Sally M. Leighton, M.S.W. \\ C.G. Jung Institute
}

ABSTRACT: This paper examines the parallels between my anestheticrelated near-death experience and Rudolph Otto's description of numinous states. I discuss Otto's arguments about such perceptions and their implications, and explore internal numinous processes such as they might be seen through Carl Jung's psychology.

During the birth of my eighth and last child, I had an experience of what William James (1958, pp. 298-302) called "anesthetic revelation." At the time, I did not know what anyone else with a psychological, philosophical, theological, or medical orientation would have called it; what I called it then and call it now was union with God. I had no choice because there $\mathrm{He}$ (or She, or Reality) was. This presence, at one stage of the experience the occasion of awe and terror, ultimately showed Himself to be so infinitely lovable that none of the theology I'd ever read had even touched Him. Beside myself with joy, I was also mystified. My training, as a Catholic in the Irish tradition, had persuaded me that such things happened only to saints, and I pondered the event for years.

I would like to examine here that experience and other subsequent psychic events in the light of Jungian theory, after first describing them more fully and placing these experiences in the context of my life. It seems to me that the symbols of transformation so encyclopedically listed in Jungian literature don't adequately address the numinosity of

Ms. Leighton is a psychotherapist in private practice, and is a member of the C.G. Jung Institute in Evanston, IL. Reprint requests should be addressed to Ms. Leighton at 105 Arlington, Elmhurst, IL 60126. 
the experience. While Carl Jung (1959, par. 481) himself believed such things occur and need to be taken into consideration, nowhere in his material published for the general public did he recount from his patients' histories anything like that which I encountered, since, as he wrote, "Psychological case histories are terra incognita to the layman," referring readers instead to "the historical material, which fully confirms the findings of modern scientific research" (Jung, 1959, par. 276).

Jung's avoidance of the concrete instance is maddening; surely anyone willing to read his works in any depth could be assumed to have a better than average grasp of psychological and theological matters, and could benefit from the inclusion of mystical experience within a "case history." It is just that hiatus I would like to fill.

I encountered the Jungian literature while working on a book of mysticism, psychology, and pharmacology, begun after taking a course in world religions. During that course, I found so many parallels between the salient features of Zen enlightenment, or satori, as outlined by D.T. Sazuki (1956), and my own anesthetic episode I was incredulous. The similarities seemed to me both sociologically and psychologically untenable, if we are the sum of our socializing, unless one assumes a common ground beneath culture that can be addressed in words beyond language, the cry of the heart that knows no tongue. Jung (1959, par. 894) referred to these correspondences as "limited to those few Christian mystics whose paradoxical statements skirt the edge of heterodoxy or actually overstep it." But I recognize the truth of this statement, since my experience did not fit my Christian expectation of what illumination might be, should I be so gifted. In the conviction that the availability of similar enlightenment experiences across cultures existed, I determined to attempt to account for them, especially when they occur in the drugged state. Later encounters in dreams with symbols of the collective unconscious have only convinced me further that there is no comparison at all in terms of impact between the two experiences, which for me remain experience of God, vis-a-vis experience of the "God-Image." Jung (1959, par. 482), of course, would have disallowed this conclusion.

\section{Experience of God}

While my counterparts in Japan were getting beaten with sticks and befogged with koans, I was leading, to the best of my ability, the life of an extremely conscientious Catholic. Until a few years before the experience of illumination and union with God, I had enjoyed all the 
"religious consolations" attached thereto. My reason, however, was confronted in several instances with the implacability of evil in the world, which I could no longer reconcile with a good God, who had, meanwhile, departed from my presence in the ways I had depended upon.

I was in what philosophers call a "limit situation," spiritually, emotionally, and physically in a state of anguish and rebellion against the canons of my church and its God. My eighth labor was going on past all reasonable time. Our saintly family doctor had been replaced by a stranger who wasn't even there. I was at a time of life when another child seemed at least one too many. My body a mass of varicose veins, a writhing, tormented creature, I felt abandoned on a cross of meaninglessness as the mid-life crisis mocked me from the wings. Can there be anyone more isolated than the person who has invested all of life's meaning in religion, and whom God has left bereft of solace? I was in despair, not fearing God so much as asking, like Job, what I had done wrong. All my old values had deserted me. I felt like a fool, an anachronism. At last I was given a shot of Demerol. Then the anesthesiologist put the mask on me, and I was asleep, all I wanted from anyone.

When I awoke, however, the mother of my fifth boy, I was in ecstasy. With a tongue thick with cotton and a mind filled with wonder, I struggled to tell the attending nurses all about God, but they laughed.

What I had experienced while anesthetized was only hinted at by St. Paul's words (I Corinthians, 2:9): "Eye hath not seen, nor ear heard, nor hath it entered into the heart of man the glory prepared for those who love him." I might have given up on God, but He hadn't given up on me. I was beside myself with the need to share the messages from my colloquy with the Lord. No wonder the nurses laughed when I babbled in my bliss, "And then God said..."

The range of the experience was vast. It picked me up from the Procrustean bed of human logic and blinded me with a vision of what lay beyond. It took my polarized notions of good and evil, and showed me how it was possible for all things to work together unto good, including my notions about the ugliness of the childbirth process. I saw how the universe works, and that the machine driving it was love, no matter how incredible that seems, given the evils and disasters inherent in natural existence, to say nothing of "sin."

I saw, finally, the meaning of "sin," and the great gift of grace, which simply means that God picks us up from one place, where we belong by nature, and takes us to Himself because He loves us out of his goodness, not out of our deserts. The encounter with God was the experience of the Holy, the one category that seems to set it apart from 
descriptions in Jung's writings as well as from psychedelic "trips" as reported in the literature. It was the ultimate silencer of human questions, convincing the experiencer of his or her own profane being.

My theology instructor recognized in my report, when I asked him for help in starting a book, all the elements of Rudolph Otto's (1971) idea of the Holy. I found confirmation therein for the universality of certain qualities of the experience that convince the experiencer utterly that he or she is in new territory. That this should have happened under the influence of drugs seemed beside the point. I felt that sometimes when we are at the end of our rope, God throws us another one; or, to be more accurate, shows us that at the end of one set of our powers there is a springboard to another plane. Immanuel Kant and Otto suggested how this may come about when nothing, apparently, has been added to human nature; I will discuss this below. At the moment, I would like to compare my experience of the Absolute with Otto's description of the Holy.

The "otherness" of the experience was obvious, one of the first categories. I had gone under anesthesia in the exact opposite of Otto's first criterion: the feeling of "creatureliness before God." I felt myself to be His disappointed friend, if not His enemy, if indeed I believed $\mathrm{He}$ existed at all. I felt in my oppressed spirit all the bitterness of the collective daughters of Eve. Yet it was in this context, which has nothing to do with inspiring stories of suffering saints, that I was plunged into "creature-feeling before the numinous." What is the "numinous?" How can the "creature-feeling" it imparts be differentiated from the kind of psychological and emotional dependency excoriated by psychiatrists as the result of an authoritarian upbringing? I can only describe it experientially. At that very extreme of rebellion and rejection of all that I had been taught about my obligation to obey God rather than man, to accept the burdens imposed by my religious tradition in the face of the ridicule of the more worldly-wise, or in Paul Tillich's (1952) phrase, having found my own "courage to be" according to my own lights, leaving God to Himself as He had left me, the vision came. I was in the presence of the Holy, and knew in a blinding illumination why God could claim anything from anyone, however absurd that "anything" appeared to be.

That this was the God of Abraham, Isaac, and Moses, the God who overwhelmed the arguments of Job, there was, for me, no doubt. My piteous cries of complaint because I had been so "good," of what anyone could claim of this Holy of Holies, were as dust. This was Goodness, the very type of which Christ had said: "One is good, God." This goodness carried the quality of essential Holiness. Simple morality was as noth- 
ing before it. For man to "do good" or "avoid evil" were minuscule concepts by contrast. It was absolutely lovable and uncontradictable. I understood at once that I existed only out of the munificence of this Being. An appreciation of the truly Holy was born; abasement before any being or force that demonstrated such purity and truth was simply a necessity. Attempts to approach this Holy were totally ineffectual; It could only be sought, It could never be found. It presents itself in Its own time for Its own reason.

Nothing of this told me that attempts to reach the Holy by way of ethical living were wrong; still, while ethical striving might help to clear the way, it was not the way; an attempt to find the truth, but not the truth. This grace of the experience of the Holy was given, it was not earned. It was added to a human nature that could make no moral claims on it.

To say that I experienced the Holy after feeling that I must reject the kind of Catholic life through which I had been trying to earn it is to say the experience only came when I had given up on it. I don't know if that is why it happened, though Jungians would be inclined to that view. It swallowed up all human reasoning in its transcendent, transparent givenness, admirability, profundity.

Accompanying such insight and awe were terror and horror at having presumed myself able to command an answer from such an overwhelmingly superior being. The sense of the mysterium tremendum, the totally other and better nature of God was absolutely convincing, arousing the full and true sense of "creaturehood." I understood that despite my own limited understanding, God could make demands on my love, loyalty, and faith while being absent from my awareness except as an absence.

After wonder, awe, and fear of the wrath of God, experienced as a reality, came a wash of total love and bliss. I would like to explain the character of that lightning switch, the amazing grace it is felt to be, but first I would like to take up the question of how this can be "true" considering that it is "irrational."

Otto, quoting Kant's Critique of Pure Reason, accounted for the possibility of imageless insight, going beyond all known categories in man's experience, in this way:

That all knowledge begins with experience there can be no doubt. For how is it possible that the faculty of cognition should be awakened into exercise otherwise than by means of objects which affect our senses? . . But, though all our knowledge begins with experience, it by no means follows that all arises out of experience. (Otto, 1971, pp. 112-113) 
Kant distinguished "that part which we receive through impressions and that which our own faculty of cognition supplies from itself, sense impressions giving merely the occasion" (Otto, 1971, p. 113).

This meant, to Otto, that:

The numinous is of the latter kind. It issues from the deepest founda. tions of cognitive apprehension that the soul possesses, and, though it of course comes into being in and amid the sensory data and empirical material of the natural world and cannot anticipate or dispense with these, yet it does not arise out of them, but only by their means. They are the incitement, the stimulus, and the occasion for the numinous experience to become astir, and, in so doing, to begin at first with naive immediacy of reaction to be interfused and interwoven with the present world of sensuous experience, until, becoming purer, it disengages itself from this and takes its stand in absolute contrast to it ... We find, that is, involved in the numinous experience, beliefs and feelings qualitatively different from anything that "natural" sense perception is capable of giving us. They are themselves not perceptions at all, but peculiar interpretations and valuations, at first of perceptual data, and then - at a higher level-of posited objects and entities, which themselves no longer belong to the perceptual world, but are thought of as supplementing and transcending it. And as they are not themselves sense-perceptions, so neither are they any sort of "transmutation" of sense-perceptions. The only "transmutation" possible in respect to sense-perception is the transformation of the intuitively given concrete percept, of whatever sort, into the corresponding concept; there is never any question of the transformation of one class of percepts into a class of entities qualitatively other. The facts of the numinous consciousness point therefore ... to a hidden substantive source, from which the religious ideas and feelings are formed, which lies in the mind independently of sense-experience; a 'pure reason' in the profoundest sense, which, because of the surpassingness of its content, must be distinguished from both the pure theoretical and the pure practical reason of Kant, as something yet higher or deeper than they. (Otto, 1971, pp. 113-114)

In this passage Otto expressed my sense of what happened to me under anesthetic, the character of which I had struggled to describe to my theology instructor. The "beliefs and feelings qualitatively different from anything that 'natural' sense is capable of giving us" involved, in my case, the deep realization that our reason is not the measure by which God is measured, though it seems to be all we have to work with, and where we must begin. It occurred to me that the impression of glorious unearthly light in the vision may have been carried there by the last impression, before I became unconscious, of the overhead lights of the delivery table. It might have been "transmuted" by that "higher" cognitive source into the realm of "surpassing- 
ness," for what I experienced was "Light of Light, True God of True God," eternal. Yet, all natural light seems a weak imitation of that original light, which was, in addition, infinitely lovable.

As Otto wrote, all such attempts to describe what is essentially a nonrational experience must be mere "ideograms," verbal hints of a transcendent category. C.S. Lewis expressed it this way:

In deepest solitude there is a road right out of the self, a commerce with something which, by refusing to identify itself with any object of the senses, or anything whereof we have biological or social need, or anything imagined, or any state of our own minds, proclaims itself purely objective. Far more objective than bodies, for it is not, like them, clothed in our senses; the naked other, imageless (though our imagination salutes it with a hundred images), unknown, undefined, undesired. (Lewis, 1956, p. 221)

Given the "wholly otherness" of the being thus encountered, the subsequent sense of unification with it becomes difficult to account for; yet "identity" with the transcendent in some mysterious process was what occurred. Following the realization of being totally unworthy and profane, and then being given a mystical vision of the unity of the universe in all its workings, I felt myself caught up into the loving heart of very reality. The overwhelming sense of love drove out terror before the Holy. "God is love" was no longer a mockery. It was experienced as the central fact of existence, here and hereafter.

The impression remains that while I was merged with God, losing, in some way, my natural identity in being incorporated into the "wholly other," I yet realized the experience through the vehicle of my deepest self. In this "natural aptitude" for identification with transcendent reality I tend to see Otto's "pure ground of the soul." It was as though all the layers of life, experience, and personality were peeled back or dropped away, allowing the naked soul to flow back to its source, a source of which it seems a part, but a discrete part. And there was communication, the essence of which was: "I love you; now you go back and love others the same way."

I went back to a darker night, senses blinded by the fire of love, knowing how far short of that goal I fell. I saw all those for whom I was responsible in the aura of their needs, and was all but crushed under the burden. For I was only an accidental mystic, not an habitual ascetic. The gift of illumination has its price; as Jung wrote (1975, p. 173): "I am profoundly mistrustful of the 'pure gifts of the gods.' You pay very dearly for them."

In any case, this was not $a$ "god-image." It was God, the numinous, 
the wrathful, the Holy, the mysterium tremendum, the light of love. Fully aware of the popular criticism that, since I had been trained in a theistic tradition my unconscious provided me with the proper divinity, on this conviction I stand; I can do no other.

\section{Experience of the "God-Image"}

There is no question that Jung's theory of the phenomenon of "enantiodromia," the reversal into the opposite, comes closer than any other in explaining psychologically the mystical experience that occurred to me under anesthesia.

Jung wrote:

It is only in the state of complete abandonment and loneliness that we experience the helpful powers of our own natures. When one has several times seen this development take place one can no longer deny that what was evil has turned into good, and that what seemed good has kept alive the forces of evil. The archdemon of egoism leads us along the road to that ingathering which religious experience demands ... (1933, p. 238)

... It is as though, at the culmination of an illness, the destructive forces were converted into healing forces. This is brought about by the fact that the archetypes come to independent life and serve as spiritual guides for the personality, thus supplanting the inadequate ego with its futile willing and striving ... The transformation takes place at the moment when in dreams or fantasies themes appear whose source in consciousness cannot be shown. To the patient it is nothing short of a revelation when, from the hidden depths of the psyche, something arises to confront him-something strange that is not the ' $\mathrm{I}$ ' and is therefore beyond the reach of personal caprice. He has gained access to the sources of psychic life, and this marks the beginning of a cure. $(1933$, p. 242)

On the surface this appears to describe the mysterium tremendum, a conversion process, an incursion of the "helpful" unconscious. Jung called the "something strange that is not the 'T', the "God-Image," not God himself, upon whom he believed it would be impossible for mortal man to gaze, since the finite cannot comprehend the infinite. He did not base this on a supernatural position, but rather on the natural, as represented in empirical evidence of the uncountable contents of the collective unconscious; the latter conceived to be available piecemeal to any person given the proper circumstances for their emergence from the substrate below the personal unconscious. He considers a given God-image a reflection in an archetypal mirror, sufficiently abstracted 
from an overwhelmingly transcendent being that it is safe to experience it, yet being so unmistakably numinous as to have healing power for those in bitter straits.

Presumably these powers are activated more effectively if one is undergoing analysis in the effort to solve one's problems. Awareness of the images is facilitated by the need to recall and report dreams. In Jungian therapy the conflicts and the work together "constellate" the healing images, if all goes well. With that, I concur; but, between that kind of experience and the experience of the Holy is a bottomless chasm.

One might presume that Jung and mystics are talking about the same thing until coming across such passages as this:

From the history of symbols as well as from the case histories of patients it can be demonstrated empirically that such a God-image actually exists, an image of wholeness which I have called the symbol of the self. It occurs most frequently in the form of mandala symbols. (Jung, 1976, par. 1495)

Here is the problem: if one has also experienced the "Otherness" of several kinds of archetypal symbols mentioned frequently in Jungian literature, one has trustworthy insight into their nature and the mysterious power of these psychic events to heal. However, if one has experienced mystical union as well, the former events are known to be weak imitations of the latter.

I shall here recount incidents of archetypal activity as they occurred to me before I had ever read a word of Jung's. They were spontaneous products activated by deep concern; I was not in analysis. In each case a period of joy, growth, and mysterious peace followed, a kind of maturing process for which I had been prepared by those symbols of transformation.

On one occasion, when I was finishing up some undergraduate work, the problem of abortion as a major ethical concern preoccupied me. I was required to write a paper for which I had researched both sides of the question. While my overt conflict involved compassion for the suffering of untold numbers of infants brought into the world uncared for as against total revulsion toward search-and-destroy missions to the womb, the subliminal issue was my whole stance as "good Catholic mother," vis-a-vis the perception that women need freedom from fertility if they are to achieve meaningful economic and emotional independence.

The values seemed irreconcilable. Mentally fatigued, I gave up working on the paper and took a nap; and in the midst of this dilemma, I 
dreamed the kind of dream of which Jung speaks. In a marvelous vision I saw all the elements of the problem, human, economic, spiritual; dark and light, good and evil, positive and negative. They whirled and danced, inextricably bound up with each other, wheat and tares together, in a vision of wholeness and goodness, not disorder and chaos.

James, in describing his repeated experience of "anesthetic revelation," wrote (1958, p. 298):

It is as if all the opposites of the world, whose contradictoriness and conflict make all our difficulties and troubles, were melted into a unity. Not only do they, as contrasted species, belong to one and the same genus, the species, the nobler and better one, is itself the genus, and so soaks up and absorbs its opposite into itself.

In my dream there was constant motion, all elements being held high through a kind of centripetal force necessary so that nothing should be lost. Somehow, apparent good and apparent evil needed each other in a transcendent sphere beyond the rational.

While the concepts and concrete objects with which my dream dealt were taken from normal consciousness and recognized as such, seen in this new and luminous way they carried the stamp of Otto's "numen" but unquestionably in a lesser form. This was not a vision of God. It did seem to represent an answer to how the problem of evil is dealt with in another dimension, indicating that God's ways are not our ways. It was a "God-image" of wholeness that I felt came from God through the unconscious.

It is of this kind of dream that Jung wrote (1933, p. 242):

That which is so effective is often the deep impression made on the patient by the independent way in which his dreams deal with his difficulties... These are manifestations of the spirit directly experienced today as they have been from time immemorial.

In itself, the paper I proceeded to write effortlessly was unimportant. As a trigger to the unconscious it was invaluable, but I believe it only acted as such because of the serious conflict of values.

It is irrational to have found reconciliation through a dream vision, but that is what happened. Erich Fromm would have objected, stating his reservations about the Jungian's conviction in this way:

In Jung's system the unconscious becomes a source of revelation, a symbol for which in religious language is God himself. In his view the fact that we are subject to the dictates of our unconscious is itself a 
religious phenomenon.... I believe ... we should approach the unconscious not as if it were a God we must worship or a dragon we must slay, but in humility, with a profound sense of humor in which we see that other part of ourselves as it really is, neither with horror nor with awe ... in dissolving repression we permit ourselves to sense the living process and to have faith in life rather than in order. (Fromm, 1972, pp. 93-94)

It is possible to agree with Fromm as far as he goes, while feeling that if he had "been there" he would know the difference.

Walter Farrell, in A Companion to the Summa (1941), saw in such phenomena "that mysterious moment of intellectual maturity when reason's intuition sees antinomies merge and still remain distinct ..." (p. 52). In the event, the "moment" does not seem "intellectual" at all, but irrational. Moreover it is clearly valued by the experiencer as an irrational with a rationale beyond reason. The dream seemed to say, "You are right to be concerned about matters of life and death, but you don't have to reconcile opposites; only God can do that."

On another occasion the power of the objective psyche burst upon me with even greater force. During the Vietnam conflict and the social upheaval concommitant to it, our children were entering college. At least partly because we parents had become involved in the civil rights movement and the war against the war, they, too, entered the fray. Anguished by the perception that their motivations did not seem altogether pure, nor their methods free of self-righteousness, we were sick with worry, especially when they seemed not at all anchored in the kind of religious conviction and life experience that grounded us. Particularly was I concerned with the contamination of peace protests with sexual revolution, drug experimentation, and increasing scorn for authority upon which society as a whole depends. Fear and concern for our children's well-being sent me to my knees to ask of the god whom I had not been addressing very often at all, "Is it I, Lord? Have our childrearing and homebuilding and social concerns been so defective that our children have to go to extremes in everything they do? Is is really $I$ out there, storming the gates of society and demanding immediate capitulation?"

Having made my plea, having wept bitterly, and finding no answer, I threw myself on my bed in despair-and after years of worry, was suddenly infused with the understanding that this was part of a process. I was not to worry, things would be all right in time. Boiled down, it was simply "Peace; be still." The storm ceased; interior joy arose. Later, when the rebellious, headstrong, idealistic teens came home with their bruises to seek comfort before going back to the fight, the 
peace was there for them. It had been given to me in what Jung would have called, after Pierre Janet, an abbaissement du niveau mental, a lowering of the threshold of consciousness, brought about by emotional exhaustion. But the breakthrough had not occurred without all the necessary ingredients: giving up, questioning my own part, and accepting defeat at the hands of life. The inner image was one of the "letting go and letting God," with perfect confidence. Its power lasted for years.

The third significant event took place six years later. For some time I had been concerned about a close friend's true attitude. We had worked together through the sixties and into the seventies in human relations, church work, and politics. We were part of a close-knit social group of couples, all involved in the same projects, working and playing together with great joie de vivre, an elite of sorts in our community. I felt the friend's loyalties were coming into question because of our lack of power and money, which had never been central to our work but with which she suddenly seemed to become obsessed. I made every allowance because of the strained conditions under which she was living at the time, was generously supportive though confused, and saw more of her than anyone else at the time. So it was not so strange that when the blow came, I was the one on whom it fell.

I went to her home to ask for some material she had promised for a campaign on which the group was working, which was past deadline for effectiveness. She was supposed to have delivered it, for which visit I had laid in a supply of her favorite soft drink. When she didn't come through, I went to ask for the material; perhaps someone else could do the job if she found herself unable for some reason. She cursed me out, crudely and brutally, with a bitterness that to this day I can't understand, except possibly as projected guilt for her future plans. Her husband apologized, but did not explain. I fled.

Until one has experienced something like this, the impact of the story of Judas cannot be felt. I was reeling. At the same time, I was somehow relieved; the truth was out, and my feeling of discomfort over many months was vindicated. But for many reasons, the insult was global, both for me and our coterie. Heartbroken, I eventually dried my tears of hurt and humiliation, tried to relax with a highball made with the soft drink supply I had bought, and retired for the night.

In that sleep I dreamed of a great dark sky in which whirled and tumbled a multitude of identical objects in chaotic disorder. Suddenly, as if at a signal, the objects rushed to the foreground, whirled briefly in spiral motion, and finally presented themselves in a perfect, luminous radial circle made of soft drink bottles. There were twelve in the arrangement, which had a gold center. It circled briefly to the right, 
stopped, and disappeared. I awoke feeling awe, wonder, and a peace that was mysterious because the event had, for me, no cognitive content to which I could ascribe this result.

At the time of this dream I knew nothing about mandala symbolism, circular motion to the right, or any of the implications of the event. Its sheer objectivity drove me to the books where I discovered its presence in man's history from antiquity. In Jungian psychology, I found much more help than elsewhere in discerning the possible meaning: the center was grievously threatened, my world was shaking, but with work, the center would hold.

The work is what the symbols of transformation are all about. A hope is given that integration is a possibility, if one contains the pain and does the work. While I didn't know this at the time, I instinctively contained the incident during the months that followed, which bore out all my fears of imminent disaster. Our circle broke up over the next year as that friend abandoned our work and joined the opposition. Trust was shattered. This became a period of introspection for me as I sorted out my personal contribution to the fractured relationship from its archetypal elements, which I came to understand more deeply years later through James Hillman's (1975) essay, "Betrayal." While I have since absorbed my own loss, that depth charge set off reverberations still felt today as a kind of group grief.

That the mandala is a symbol of the self appears to be beyond doubt. Its power to grip the soul when it is experienced in this spontaneous way can hardly be exaggerated. By way of contrast, two other dreams during the same week, while speaking directly to my condition in intelligible ways for the psychologically inclined, did not have the same impact. Filled with compensating beauty for my conscious misery, they did contain both promise and warning about the individuation process, about which, as such, I knew nothing at the time. I did realize I was questioning the whole basis of my life: family, friends, social action, world. That way at least the threat of madness lies.

All these dreams I consider signposts toward the transcendent, images pointing beyond themselves to an ordering process, an ultimate concern, streetlamps for dark stretches of road. Chronologically they would appear thus: personal concern for my own children's safety, body and soul; abortion as a current ethical problem having broader tragic human implications; then the whole meaning of personal relations and political action, inner and outer, values about which I had been very confident until a single searing moment. The images raised by the traumata caused me to detach from the concrete, putting me in touch with basic human elements behind them, universals in life stages. 
Still, can anyone imagine that even these powerfully reassuring experiences with their enduring results are anything but a pale reflection of that totally other encountered years ago? Revised and corrected versions of my view of reality, perhaps; reclaimed and rehabilitated garbage from my life's dungheap, maybe. But God? No; except in the protean forms He takes to entice and elude and drive us relentlessly on to grasp His reality in our own, to find Him in anguish as well as exultation.

It may be a matter of speculation for Jungians why the unitive experience appeared achronologically, since Jung himself (1976, par. 1331) would have expected the reverse order. My own feeling is that I was given an experience of the Omega in order to bear the long, tortuous way that leads from the Alpha. I conclude that God could and did skip me past endless rungs of the ladder to give me a glimpse of the goal, then sent me back to laboriously work out the middle distance inch by inch, an exercise often endurable only because of that indelible memory that contains reason to hope.

Thus I take my stand with those "very peculiar people ... who think that one can make anything but a conceptual distinction between the individual experience of God and God himself" (Jung, 1959, par. 482). If I'm wrong, it will take God Himself to straighten me out, since it was He who convinced me in the first place.

\section{References}

Farrell, W. (1941). A companion to the summa Volume I. New York, NY: Sheed and Ward.

Fromm, E. (1972). Psychoanalysis and religion. New York, NY: Bantam.

Hillman, J. (1975). Loose ends. Zurich, Switzerland: Spring.

James, William. (1958). Varieties of religious experience. New York, NY: New American Library.

Jung, C.G. (1933). Modern man in search of a soul. New York, NY: Harcourt, Brace, and World.

Jung, C.G. (1959). Brother Klaus. In The collected works of C.G. Jung. Volume 11: Psychology and religion. (Adler, G., ed.; Hull, R.F.C., trans.). Princeton, NJ: Princeton University Press.

Jung, C.G. (1975). Letters. (Hull, R.F.C., trans.). Princeton, NJ: Princeton University Press.

Jung, C.G. (1976). Foreword to Allenby: "A psychological study of the origins of monotheism." In The Collected Works of C.G. Jung. Volume 18: The symbolic life. (Adler, G., ed.; Hull, R.F.C., trans.). Princeton, NJ: Princeton University Press.

Lewis, C.S. (1956). Surprised by joy. New York, NY: Harcourt, Brace.

Otto, R. (1971). The idea of the holy. New York, NY: Oxford University Press.

Suzuki, D.T. (1956). Zen Buddhism. Garden City, NY: Doubleday.

Tillich, P. (1952). The courage to be. New Haven, CT: Yale University Press. 